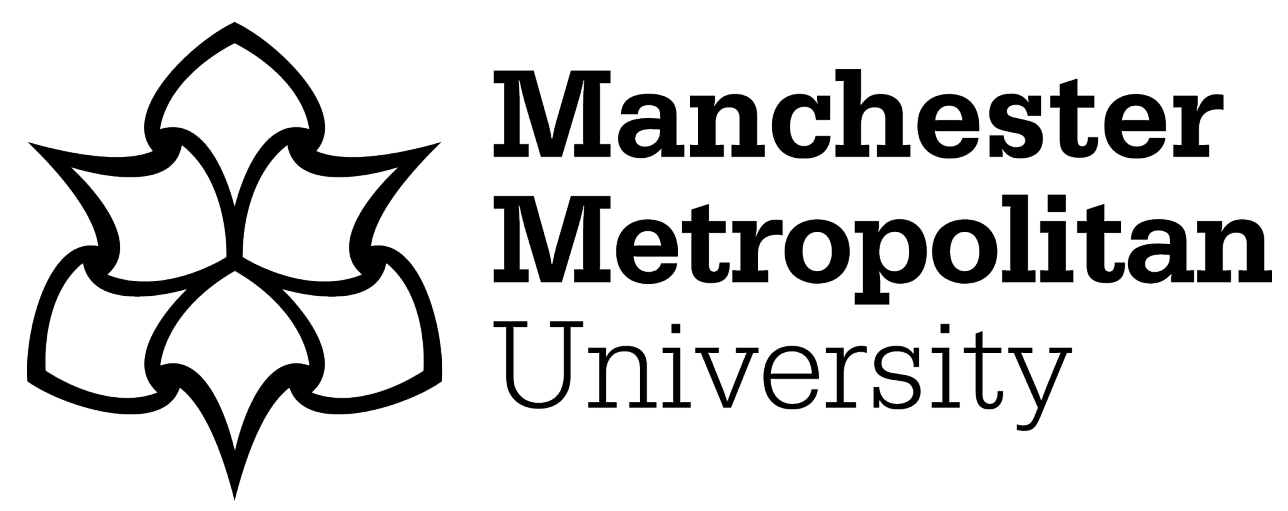

Duggan, James (2021) The co-productive imagination: a creative, speculative and eventful approach to co-producing research. International Journal of Social Research Methodology, 24 (3). pp. 355-367. ISSN 1364-5579

Downloaded from: https://e-space.mmu.ac.uk/626280/

Version: Accepted Version

Publisher: Informa UK Limited

DOI: https://doi.org/10.1080/13645579.2020.1799638

Please cite the published version 
1 The co-productive imagination: A creative, speculative and eventful approach to co-

\title{
producing research
}

\begin{abstract}
This article explores the co-production of research as creative, speculative, and eventful rather than as research processes determined by equality, empowerment and social justice. There are persuasive critiques of participatory and co-produced methods. In response, the case is made for focusing instead on the complex processes through which ideas, affects and relational capacities emerge, are nurtured or obscured, and circulate as part of the complex processes of co-producing research. The argument is developed with reference to a recent research project on youth loneliness. Through process philosophy and speculative approaches, the co-productive imagination illuminates the necessary imaginative work of conceiving propositions, techniques of relation and methodological tactics that move us through creative advance to eventful realisations that something in our research matters! Through an ethics of the event the aim of research becomes collaboratively creating new potentials in a world in process.
\end{abstract}

Keywords: Co-production, Whitehead, event, speculative, youth loneliness

\section{Introduction}

The co-productive imagination attempts to rethink the co-production of research as creative, speculative, and eventful rather than as processes determined by equality, empowerment and social justice. Ostrom (1996) coined 'co-production' to illuminate the reciprocal exchanges between public services and communities in the delivery of public goods, such as law and order. Co-production has since come to occupy a prominent position in global policy and practice imaginaries (Bevir, 2019). The coproductive trend in research is indicative of demands on academia to become more relevant, and produce greater value for society (British Academy, 2010). The Arts and Humanities Research Council's Connected Communities programme was a significant and illustrative response, funding over 300 projects, with genuine commitments for community-university partnerships and co-production (Facer \& Pahl, 2017). Coproduction is now a popular and plural repertoire of research practices for the collaborative production of knowledge between professional researchers (e.g. 
academics) and those traditionally thought of as participants and/or the objects of study (e.g. young people) (Facer \& Enright, 2016).

This article contributes to the field of co-producing research by re-imagining it as creative and eventful. Co-producing research is often defined through terms such as equality, empowerment, emancipation, democracy, and social justice approaches (e.g. Beebeejaun, Durose, Rees, Richardson \& Richardson, 2015). In addition to a persuasive critique of the laudable rhetoric of participatory and co-produced practice (e.g., Cooke and Kothari, 2001, Ersoy, 2017), it is not always clear what equality or empowerment mean in the singularities of practice. The article emerges from the Loneliness Connects Us project (2016-2019) (Batsleer \& Duggan, 2020), which aimed to work with young people to produce new ways of navigating loneliness, and including youth voices in a national conversation on loneliness. We began the project committing to youth 'co-research' as co-producing research felt too restrictive (Bradbury-Jones \& Taylor, 2015). This decision was challenged after an eventful realisation that one of the youth co-researchers - Patience (anonymised name) - was practising an expansive form of care that was crucial to co-producing the project's aim of young people collectively exploring loneliness. Following the trajectory of this emerging finding questions leading accounts of co-production as equality or empowerment. It warrants developing new approaches to the co-production of research. This article, therefore, speculatively re-imagines Loneliness Connects Us as illustrative of eventful co-production. The case is developed through sections on: coproduction as creativity under constraint, a speculative and eventful account of coproduction, an overview of the project, a description of the carousel of moving methods that represent the methodology, three sections following the trajectory of an emerging finding through three empirical moments (relationship, workshop, email), and a conclusion scoping the potential of eventful practices for co-producing research.

\section{Co-production as creativity under constraint}

Co-producing research works to decentre, unsettle and disrupt spaces, relations of power and authority across the production of knowledge between academia and the communities beyond. Whether orientated 'within, against or beyond the university' (Bell \& Pahl, 2018), co-production provides a necessary space for academics and 
communities to challenge elitist and exclusionary knowledge production cultures. It invites us to unlearn the inheritances of academia as a society of letters. It is the space to explore research practices that venture 'beyond text' and academia's logocentrism (Beebeejaun, Durose, Rees, Richardson, \& Richardson, 2014), work 'beyond critique' and construct just alternatives in and with communities (Perry \& Atherton, 2017), and rethink theory building in relation to living knowledges (Facer \& Enright, 2016). The reconceptualization of knowledge and knowledge production demands we re-think and re-value the legacies of research (Pahl \& Facer, 2016), and the practices and media for knowledge production and dissemination beyond academic books and articles, including 'podcasts, zines, artworks, films, exhibitions, posters, apps, guided walks, pamphlets and soundwalks' (Bell \& Pahl, 2018, p.110).

As necessary as the co-productive turn is, a recurrent concern is that co-production is a worldly concept that must travel from theory and rhetoric to contested and complex application (Innes, Davies \& McDermot, 2019). A long-established critique of the claims of participatory and co-produced modes of working defines participation as a form of tyranny (Cooke \& Kothari, 2001). Young people are conceptualised in deficit; to be trained, socialised and made subject to practices that serve society's needs (Foucault, 1997, Vromen \& Collin, 2010). The institutional context of academia entrenches young peoples contrived participation in research (Dentith, Measor \& O'Malley 2009, Fox, 2013). Within the neoliberalising and performative structures of accelerating academia (Vostal, 2016), temporal pressures constrain researchers' capacities to sufficiently nurture the relationships required for genuine co-production (Enright, Facer \& Larner, 2016). Academics therefore must protect against modes of research that extract the value and capitals of the rich social and cultural achievements of communities beyond academia (Autonomous Geographies Collective, 2010). Howsoever significant the challenges, co-production is a necessary process for re-negotiating and re-imagining the relationships between academia, the public, and knowledge production. The contexts in which research is co-produced are inherently contested, constrained and messy (Thomas-Hughes, 2018b). If co-production is implicated in governmentality strategies and the 'conduct of conduct' (Ersoy, 2017) 
the question is, how we engage, 'the art of not being governed quite so much' (Foucault, 2007, p. 45) as we co-produce and through co-production?

A useful departure point is the common orientation for co-production to develop equal relationships throughout the research process. Equality in co-production is problematized, theorised and enacted in diverse ways including commitments to empower or equalise power relations (Beebeejaun, et al., 2014), enact democracy or democratise research (Kara, 2017), emancipate participants (Liddiard et al., 2019) or realise social justice through social change (Banks, Hart, Pahl \& Ward, 2018, Perry \& Atherton, 2017). Although not universal (e.g. Perry \& Atherton, 2017), co-production as equality involves including community co-producers in the research, from agenda setting and planning to data analysis and the dissemination of findings (e.g. Hickey, Richards, \& Sheehy 2018, Liddiard et al. 2019). The justification for continuous participation is found in the intersecting influences of: rights-based discourses and the right of the child to be included in decisions that affect them (United Nations, 1989); the claimed epistemological benefits of developing more relevant and useful knowledge with communities (Durose, Beebeejaun, Rees, Richardson \& Richardson, 2011); emancipatory and activist orientations (Liddiard, et al., 2019); and providing young people with agency within a project, control over and ownership of the data and outputs (Banks et al., 2013).

Do the emphases on co-production as equality and empowerment through continuous participation, however, create forms of unnecessary exclusion? One, coproduced projects are often complex, constituted of multiple types of people and groups (e.g. academics, practitioners, artists, young people, funders, participants) performing various roles (e.g. catalyzer, scholar, broker and project manager) at different stages of a project (Facer \& Enright, 2016). The orientation towards equality in navigating this terrain is crucial but what does it mean to empower, enact democratic or socially just research across diverse domains and extended timescales? Are young people without the resources or stability to make sustained commitments excluded from participating? Two, equality as continuous participation is a focus in coproduction in public service contexts (e.g. Pemberton \& Mason, 2009) which typically relate to transforming the relationships between groups that rely on services and 
public or clinical services (e.g. Nesta, 2012). Despite similarities there are significant differences between knowledge co-production through research and co-production as innovation in public service delivery. Three, the assumption that including young people in research tasks is necessarily meaningful and empowering is troubled by the post-qualitative turn which identifies the social construction of, 'conventional humanist qualitative methodology... invented to respond to the [qualitativequantitative] paradigm wars' (St. Pierre, 2019). Why, for example, is planning and conducting an interview empowering?

Rather than defining and justifying co-production as equality or empowerment a more productive approach is to explore what ways of theorising and practising research are adequate to understanding the complexity of the world, and attending carefully to the processes (Perry \& Atherton, 2017) and micro-socialities of co-producing research (Rogaly, 2016). Process and speculative approaches are foundationally committed to thinking amidst a world in process. Thus, we can reconfigure co-production as creativity under conditions of constraint with attention to eventful processes of imagination and creativity. This rationale justifies this speculative adventure thinking the Loneliness Connects Us as illustrative of a more expansive form of co-producing research.

\section{Processes for eventful co-production}

146 The co-productive imagination builds on A.N. Whitehead's $(1967,1978)$ process 147 philosophy and its descendants: speculative realism (Shaviro, 2009), activist 148 philosophy (Massumi, 2011) and constructivist philosophy (Stengers, 2011, 2019). 149 Whitehead in some senses prefigured the co-productive turn. He cautioned that our 150 prized academic training, disciplines and theorising prevents us from engaging 151 productively with a world in process. If we maintain abstract academic categories then 152 our mind resides in a 'groove', our intellectual adventures explore the same territories, 153 and 'the remainder of life is treated superficially' (Whitehead, 1967, p. 197). This 154 remainder is what oftentimes makes lives meaningful and co-produced research vital. 155 Categories such as production/co-production, service-producer/service-user, 156 academic/young person, co-produced research/ethnography focus our thinking on 157 particular ideas, rationalities and spaces - but what remainders do they obscure? 
Whitehead illuminates our fraught relationship with ideas and concepts that we cannot think without yet are 'not a human creation... [but] powerful and demanding "other-than-humans"' (Stengers, 2019, p.14). We are moved to wonder: what does co-production demand of us, make us feel, enable us to do?

This shift requires thinking in terms of the dynamic processes of 'events' rather than understanding the world through a humanistic perspective of knowing humans (e.g., I know) and known objects (e.g., the ball is round). To understand what events are, how they emerge and are realized, for the purpose of this article, imagine a sea where each drop of water is a drop of experience (Whitehead, 1978). These drops of experience are called actual entities or actual occasions and they are the primary form of experience. Rather than we humans, they feel or 'prehend' and are felt or 'prehended' through 'prehensive exchange[s] of affective data' (Rousell, 2017, p. 16). Each of these actual entities is the singular outcome from a previous event. The singularity of each means there is huge diversity amongst them. It is this diversity that represents the potential and possibility for new things to emerge through eventful realisation (Whitehead, 1978, Massumi, 2011). Events are pulsing and overlapping waves of creation, novelty and invention where diversity becomes singularity and the emergence of a new drop of experience, or actual entity. They are onto-genetic to experience, meaning they define the world's becoming and bringing into being (Massumi, 2011). Events can be profound, relating to the 'collective thinking of something that sets something new into motion.' (Stengers in Manning and Massumi, 2014, p.90) Events can be microscopic, relating to the change through time of nonhuman structures such as Cleopatra's Needle in London from one second to the next (Whitehead, 1964).

Thinking co-production as eventful realisations orientates us to singularity, creativity and the continual processes of bringing creative potentials together, attuning and attending to the emerging potentials. Co-production becomes centrally focused on imaginative work and the necessary task of developing our vigilance and our, [C]apacity to answer the cry "It Matters" ... a transformation of the way a situation - always this situation - may challenge our modes of abstraction. (Stengers, 2019, p.15) 
Stengers (2019) writes that answering the cry It Matters involves the 'cultivation' and 'awakening of the imagination' (pp. 16-17). This imagination relates to the 'questioning of situations' (Souriau, 2015 cited in Stengers 2019), and the ability to artfully attend to the challenges in a particular sensible situation and nurture 'new ways of making sense in common - experimenting with the very "ontology of ourselves"' (Stengers, 2019, p.4). This experimentation occurs amongst the flux and fluidity of a world in process and so our task is not to make definite statements on what the world is as it will have already changed but rather,

For Whitehead 'philosophy is akin to poetry': its descriptions are carefully constructed utterances (poesis) 'requiring a leap of the imagination'[creating] lures for feeling, and by extension for thought and action... (Gaskill and Nocek, 2014, p.8).

The rhythm of the co-productive imagination is found in the expansive adventures of thinking and feeling, cohered through the creative advance towards the verification that It Matters! The following sections describe the application the co-productive imagination through the Loneliness Connects Us inquiry, the ethics of the event, and the techniques of relation and appetition that created the conditions for the eventful realisation that Patience was practising an expansive politics of care.

\section{Loneliness Connects Us}

Loneliness Connects Us aimed to work with a group of young people to research youth loneliness and amplify the findings into an emerging national conversation about loneliness, providing useful knowledge to help young people navigate loneliness. Realising these aims required creating spaces in which individual young people felt able to have conversations and encounters that matter about the sensitive subject of loneliness. In addition, we wanted to broaden the inquiry: First, geographically by developing the research in different places across the UK. Second, by locating the dialogue in the context of neoliberalising discourses and pedagogies in which issues such as loneliness are individualised and pathologised, with young people made responsible for being resilient to adversity (Fisher, 2009, Kelly, 2001). The project therefore was complex, running from November 2016 to July 2019 and included 22 adults working with and for a group of 14 core youth co-researchers and engaging 
over 200 young people. The challenge was how to reconcile co-production understood as enacting equal and empowering relationships if through the project there were so

222 many diverse forms of encounters with young people. Was it enough to empower 223 some young people at some points, while having less empowering or equal 224 interactions with others? What about potentially powerful ideas that emerged in the 225 cracks and liminal spaces of temporary and peripheral interactions with young 226 people?

227 Thinking co-production as event provides a route for reconciling the challenge 228 between working with specific individual young people in relation to producing 229 interesting thoughts and feelings. Instead of an orientation towards what is equal and 230 common, the ethics of the event is, 'to what is irreducibly singular' (Manning and 231 Massumi, 2014, p.108). There is an emphasis on the differentials and diversity of those 232 forces present, which contribute to the realisation of an event. Rather than a personal 233 ethics, 'a collective practice of care' is a more aligned to a political virtue wherein 234 caring for individuals is folded into an overall concern for the processes of nurturing 235 and realising events (Manning and Massumi, 2014, p. 108). For Stengers this includes, 236 'allowing ourselves to be touched, and artfully giving to what touches us the power to 237 make us imagine, think, and learn' (p.18).

238 In terms of mobilising Whitehead's process philosophy, research creation represents 239 the most influential practice closest to the ambitions of this project. Research creation 240 engages with art as theory and research, rather than art as means of knowledge 241 dissemination (Truman \& Springgay, 2015). Loneliness Connects Us was instead 242 grounded in practices from youth work and creative, arts-based and co-produced 243 methods that are foundationally committed to openness and developing authentic 244 and equal relationships with young people (de St Croix, 2016). Although arguably not 245 as theoretically ambitious and pioneering as research creation, the commitment to 246 youth work was essential for our ethical and productive engagement with the young 247 people.

248 The research ethics progressed beyond standard guidelines to engage with spatialities 249 of care for the youth co-researchers and events. The research followed standard 250 university and professional ethics guidelines, including, for example, securing and 
251 protecting voluntary informed consent from young people and from the parents of 252 children under-16 (BERA, 2011). We invested in a project infrastructure that attended

253 to a politics of space, and the necessary conditions of conviviality and care required to 254 co-produce research (Bell \& Pahl, 2018). Locating the research in a youth mental 255 health organisation was significant as engagements with loneliness are potentially 256 traumatic. As an ethical commitment we wanted the young people to be able to access 257 pastoral and counselling support within the project infrastructure and not signpost 258 them to mental health services where there might be a significant wait for referral and 259 service delivery.

\section{A carousel of moving methods}

261 We initiated the research through a carousel of moving methods, an iterative and 262 expansive series of encounters and conversations that matter with youth co263 researchers. Loneliness is a universal experience but profoundly social, complex, 264 relational and granular in its manifestations. Loneliness might be too painful to 265 confront and articulate in words; but dance, movement and improvisation might help embody and encounter emotions otherwise inexpressible (Levy, 2005). Whereas film or music could act as a familiar and safe set of cultural practices to consider loneliness in one's life or in the apparent safety of imagined characters. We believed plural and expansive research methodologies and approaches would afford diverse vantagepoints of the singularities and diversities of loneliness.

271 The carousel involved the imaginative work of creating a series of 'lures for feeling' for encountering loneliness, in the form of various propositions or techniques of relation.

273 Propositions can be speculative and conceptual, like Haraway's (1985) cyborg in the

274 Cyborg Manifesto. Or, they can take the form of 'techniques of relation,' which are immanent and processual devices or practices for initiating creative and eventful encounters (Manning and Massumi, 2014). These techniques are iterative, expansive

277 and mobile, creating ways of interacting in research contexts and whose potential can 278 be explored and developed. 'They are springboards... they activate a practice from 279 within. They set in motion.' (Manning and Massumi, 2014, p. ix)

280 An important feature of the carousel was that we did not seek to perfect a singular method, proposition or lure for feeling but rather engage with loneliness expansively 
and diversely, inspired by the notion of 'appetition.' Appetition describes the restless appetite towards difference, differentials and the diverse data that create novelty and 284 transformation (Shaviro, 2009, pp. 90-91). Determined by the eventful movement of diversity into singularity and the challenge of knowing in a world in process, we are moved to encounter ever more diverse dimensions of experience and put our propositions and ideas to work there. The carousel developed through a deep concern with how ideas, people and an array of affective and material forces come together in creative research processes.

290 One form of appetition was the movement through different techniques of relation in the research, and ways of relating to one another and feelings of loneliness. There is not space to describe the entire process of weekly meetings. In the beginning the academic team took a greater role in conceiving the techniques of relation and workshop design. The carousel began with a session on interviewing practice and practical research ethics. A second session focused on community philosophy (Tiffany, 2009), which encourages talking, listening, and thinking together. We ran subsequent sessions that drew together 'patterned contrasts' in the rough and ready arrangement of differentials and diversity to create the eventful conditions for creativity (Shaviro, 2009, p.69). There were sessions that explored loneliness together through discussions about music and film or playful methods that moved the research out of the workshop space and into the street. In one session, a physical-technology practitioner joined the group and we made DIY robots out of cardboard, pens and a small vibrating motor for propulsion. The diversity of ideas, materials, affects, relations, the arrangement of bodies - side-by-side and eyes following hands occupied 305 twisting and fixing cardboard, rather than face-to-face conversations - were imaginative propositions providing lures for prehending new ways of thinking-feeling 307 loneliness. Some ideas and practices gained greater power and persisted or 308 disappeared, the motivating orientation being whether they set something in motion, whether something mattered. Throughout the carousel, the academic researchers encouraged the youth co-researchers to take a greater role in conceiving the 311 constitutive techniques of relation and propositions to define their and our encounters with loneliness. 
313 A second form of movement through the carousel was that of the young people. A 314 core team of 14 young people were central to the project's development. However, 315 apart from a paid youth co-researcher, none participated throughout. Another approximately 186 young people joined for various reasons and lengths of time, for example, as an activity for a university assignment, to 'hang out', or as participants in interviews and workshops led by the academic and/or youth co-researchers. Some young people engaged and continued to participate whereas others disengaged or chose not to participate. We aimed to value temporary and peripheral encounters with the project as much as those by young people unable to spend more time participating.

Amongst the appetitive and expansive drive of the research to incorporate more and diverse techniques of relation, encounters with loneliness, and young people's life experience - the research was focused by an overall concern for verification. The coproductive imagination is focused on a lure's or a proposition's capacity to, 'transform our modes of thought, the habits of attention and interest that shape our engagements with the world.' (Gaskill and Noceck, 2014, p.11) The following sections present the empirical content following the trajectory of one emerging finding in the growing importance of the relationship between Patience and Mark, and the tactics and happenings that enabled my eventful realisation of Patience's expansive capacities of care during the project.

\section{Relationship}

334 In the carousel's early phase, it was apparent in many ways that 'somethings-doing' 335 (Massumi, 2011, p.5) but not whether or if any of It Matters! There were changing configurations of academic researchers and youth co-researchers attending the weekly meetings. All of us were present in the space with undisclosed histories of mental health issues and loneliness, attuning and attending to one another across

340 loneliness and vulnerability. Amongst this Patience and Mark represented an unusual 341 and increasingly interesting relationship.

342 Patience joined the project before Mark. She was a somewhat enigmatic presence, 343 seemingly aloof and bemused by the project but also clearly committed to helping 
344 young people with mental health issues. She regularly attended meetings and 345 volunteered for the community partner's youth ambassador programme. Patience 346 was quiet and reserved in the sessions, appreciating others' contributions but not 347 volunteering her thoughts. When she spoke, it was obvious she had thought deeply about loneliness. The academic team wanted to provide diverse opportunities for the 349 youth co-producers to develop the research in line with their interests. Patience played the piano. As part of the evolving and imaginative work of the project we conceived an 'enabling constraint' (Manning \& Massumi, 2014, p.93). We invited the young people to play music that evoked feelings about loneliness, and we would listen and discuss it. Patience played a song from the movie score to the 1986 film The Mission. The music was from a scene after the Guaraní warriors attached a missionary to a cross and sent him over the waterfall to his death. A Jesuit Priest climbs to the top of the waterfall to play his oboe to the Guaraní to plead for his life. The oboe was set apart from the rest of the orchestra, Patience explained. It sounded lonely.

358 Mark joined several months later. After eight carousel sessions we hosted participatory data analysis workshop to articulate the research agenda and associated methods. Mark arrived late and was anxious that he had somehow annoyed the other young people and was not welcome. Mark's anxieties were a continual concern for me. At times I consulted the community partner's mental health practitioners to ascertain if he was a risk to himself. Yet at other times we would laugh hysterically while, for example, we walked to buy falafel wraps for the group and Mark did impressions of 1990's Jungle MCs played on poor-quality tapes.

Much more could be written about Mark and Patience's relationship but in 367 Whitehead's scheme, we are thinking in a world in process, so, 'it is more important that a proposition be interesting than that it be true' (1967, p. 259). Mark and Patience's relationship was interesting. They tended towards opposites of various personal characteristics, such as sociability and conflict resolution. At the time it could not be anticipated that the relationship of support, care and friendship between

372 Patience and Mark would become something that mattered to the research. Indeed, 373 the appetition and drive to make more diverse encounters meant that no one could be sure where the research was going but that more diverse encounters would with 
imagination work towards an eventful realisation. Yet through the unfolding of the research, and the complex relations beyond the project, Patience and Mark were busy, doing things - turning up together, laughing at jokes, caring for one another producing data, and the growing inheritances of potentials that would create tendencies for the research to eventfully realise.

\section{Workshop}

During one session seven months into the project, a group of six co-researchers were planning a radio show on youth loneliness. Patience and Mark arrived late, as they were working on another arts project held on the same night. The lead youth coresearcher asked the group, what should be in the programme? Mark immediately launched into a series of comments, which were received in an uneasy silence,

Can we do a show about how trans parents are having kids and not calling the kids a boy or a girl but making them trans kids? I'm all for adults being trans and whatever but they shouldn't impose that on kids. Leave them out of it... Could we look at political correctness? I want to know why if I'm talking to a woman, I'm 'mansplaining'. It's fucking annoying. I'm just talking... What about why there's no men's group here? There's 3 LGBT groups but none (just) for men. Why's that?

These outbursts were a regular feature of the group. However, where before we had engaged or challenged Mark, this time the response of the group was muted and noncommittal.

Mark was present with experiences of loneliness, depression and pain. Lonely people tend to exaggerate the level of social threat they are encountering - the psychological effect 'hypervigilance' - and can be anxious and awkward (Qualter et al., 2013). We do not, therefore, encounter loneliness as an abstract category but rather we experience the singularity of a young man sitting amongst others, his loud and potentially transphobic outbursts during sessions when we are trying to conduct research. A swirling sea of words, affects and desires.

I was unsure how to react: Protect Mark, challenge his views, or observe? As I understand them, his outbursts challenged the inclusive project space. The prerogative to self-define pronouns and gender identity are embraced in the organisation. It is a microcosm of the societal trends that he feels alienate him. He is, 
however, young and attends the project to receive support for mental health issues. Under austerity politics there has been a massive disinvestment in youth mental 409 health services (Youdell and McGimpsey, 2015), creating fewer opportunities for young people to meet in safe spaces that fit their preferences. Research projects are one way of funding youth provision, keeping 'the doors open.' I was careful not to occupy this space of youth sociality and peer-support, not positioning myself to empower or manage the young people. Sometimes the young people's motivation in the space was seemingly dedication to conduct research to better understand loneliness. At other times the project was more diversion, where the young people wanted to socialise and have fun. So, I sat and observed. Looking around the group I noticed Patience seemingly uncomfortable but also looking around to the other coresearchers. Her glances and appeals to the other co-researchers seemed to me to be actively including Mark in the space, intoning: This is not all he is. He needs to be here. We are here for each other.

421 The significance of this event - its potential to transform our modes of thought would be born out yet in that moment my capacities to be open and to attune to this sensible moment were closed. I was preparing a conference presentation on masculinity and loneliness. I felt Mark's 'banter', an aggressive and transgressive form of humour, and the way it often alienated him from the support and connection he seemingly desired would be a fascinating focus for the presentation. I noticed Patience, but did not comprehend the potential of this event. Again, this, which is to say what would come to matter at least here in this article, I did not at that time feel It Matters! Yet, events are 'full of oneness and manyness' (James 1996, pp. 93-94 cited in 430 Massumi 2011, p.5) Patience's silent looks and appeals created data that added to the 431 diversity of creative potentials that would be realised through subsequent events as new possibilities, of modes and ways of being in the world.

\section{The Email}

434 The rhythm of the co-productive imagination is found in the expansive adventures of thinking and feeling, cohered through the creative advance towards the verification

436 that It Matters! The concern for verification focuses on a lure's or a proposition's 437 capacity to, 'transform our modes of thought, the habits of attention and interest that 

shape our engagements with the world.' (Gaskill \& Noceck, 2014, p.11) The movement towards verification occurs through our experience of the world and out prehension or feeling, which has specific implications for co-producing research.

According to Whitehead, there is nothing beyond or outside of experience, and our feeling or prehension of it (Shaviro, 2009). We experience the world through an endless series of eventful moments: Mark's outburst. Patience's silent interventions to include Mark. My moments of inaction during the session, and now as I write this sentence - choosing from a diverse range of words tending towards the next word and the next with each one committed to the page. You, at your desk, reading this text. These are all events. Events become and perish, amidst a sea of pulsing waves moving from diversity to eventful singularity and the creation of something new, an actual entity, which creates the potential for yet more eventful realisations. The emotional basis of experience, in Whitehead's scheme, means the realisation or culmination of events is described as 'satisfaction' (Whitehead, 1978). The task of research therefore is in deepening and intensifying this emotional experience through the creative advance, 'an intensive, qualitative, and aesthetic drive for 'depth of satisfaction' (Shaviro, 2009, p.70).

In Loneliness Connects Us project the culmination of the processes of creative advance culminated in an eventful moment while I was sitting in my office, at my laptop answering emails after the sessions with the youth co-researchers had finished. The academic team had written the Loneliness Connects Us research report (Batsleer \& Duggan, 2018). We were developing strategies for sharing the findings in ways that would help young people navigate experiences of loneliness, including a list of recommendations. One recommendation was to increase capacities for 'friendship, mutuality, association and co-operation' (p.50). This concern to be with one another in difference and vulnerability, discussing feelings of loneliness, was central to the research. It was not clear how these concepts ought to be translated and enacted, and whether I realized them in specific encounters especially when working with Mark. Following Whitehead, I wondered whether these abstractions - 'friendship' as with 'empower' and 'co-production' - were mere grooves for my mind. Were these ideas 
and practices non-human others, with powerful potentials to illuminate or obscure my openness to imaginatively and expansively engage with a world in process?

470

471

472

473

I received an email from the research funder. It asked if they could use one of the coresearcher's quotes for the title of an up-coming report. The quote was excerpted from an interview I conducted with Patience. She said,

Loneliness means something different to everyone because everyone experiences things differently. But I don't think people should be afraid of loneliness. All your emotions are important ... if you're lonely it means you're missing out on something. You need that social connection.

The fund representative asked if they could change the quote as the tone, and specifically 'your emotions', was too didactic for a report written by adults for young people. I agreed to the change, and the report was titled, All Our Emotions are Important (Co-op Foundation, 2018). Thinking co-production as equality and by ownership of data (Banks et al., 2013) my consent arguably infringed Patience's ownership of her data. I was and continue to be, however, more concerned with the easy acceptance of Patience's quote.

The quote's tone reflects neoliberalising discourses and pedagogies inculcating youth resilience, character and grit in the face of life's adversity. We can read into it an understanding of loneliness as an adaptive drive towards social connection, as hunger is a drive to eat (Cacioppo \& Patrick, 2009). Furthermore, indicative of the self-help genre, the statement voices the thinking and wise ' $I$ ' demystifying the world for the unaware 'you.' Young people are positioned to include themselves in the social connection they desire. Youth loneliness becomes yet another aspect of human experience and conduct interpolated within neoliberalising governmentality strategies. Janet Batsleer - the principal investigator - was always clear that self-help is okay but not if lonely young people cannot help themselves. Patience's quote abstracted and amplified as the words became text, and as evidence might become a resource for the subsequent imaginative work of denying capacities to act through policy making in austerity contexts. 
Sitting in my chair I initiated in an adventure of thought, departing from the proposition: Patience's ways of relating to other members of the group went beyond mere neoliberalising social relations. Patience was evidently versed in dominant discourses - psychology and self-help - relating to loneliness. Yet the research's commitment to appetition and expansively exploring loneliness through plurality had produced diverse encounters of singularity and difference: Mark in the project space and outside. Patience's art exhibition in another project. Eating together in a restaurant. Listening to music together. Arguing and making space for one another. And, finally, translating these events into text for funders and policy makers. It was these shifts and translating and re-proposing the research to the policy domain that worked to intensify the happening of the event towards its satisfaction. In Whitehead's scheme difference is fundamental to creativity, as lightening's "appearance is conditioned by an electro-magnetic differential" between positive and negative charges (Massumi, 2012, p21). Here we can indicate the research developing towards an eventful culmination through forms of creative advance, as, Emotions are intensified, and experiences made richer, when incompatibilities, instead of being excluded (negatively prehended), are transformed into contrasts that can be positively integrated within a greater "complexity of order"... (Shaviro, 2009, p.69)

I came to resist the abstraction of co-producing research to particular contexts and spaces where young people were present; instead in my research practice remained open and sought to search for diversity and difference while nurturing the unfolding potentials of the research through an ethics of the event. Rather than equality or empowerment, co-production becomes responding to the insistence of the cry 'It matters!'... intensifying it... [and] giving to it the power to problematize what we ask our reasons to do and what they do to us, how they matter for us and how they make things matter. (Stengers, 2019, p. 16)

The event was realising Patience's profound contributions to the project that the quote failed to capture and that I had previously failed to appreciate. In the multiplicity of the eventful unfolding of the research, as I struggled over whether I was researching or being with another human next to a potentially lonely young man, 
Patience was patient and open to the moment. Her relationship with Mark affirmed a genuine embodiment of a more expansive relationship of care, friendship and the capacity to relate to people experiencing loneliness and the accompanying anxiety. Significantly, this suggests a more challenging relational politics of friendship and obligation under the social and emotional conditions of neoliberalism (May, 2012). We may propose to young people, if you are feeling lonely then you need to take action to increase your social connection but we need to be there for you even if you are awkward and anxious, or we are trying to do research.

\section{Conclusion}

This article was an adventure of thought: Suspending notions of co-production as enacting equality, instead re-imagining it as creative and eventful through speculative and process approaches. The work's originality is justified as the first application of process and speculative approaches to the field of research co-production. The significance of the shift is that it provides a clearer account of what it is we do when we co-produce research, and why. Although grounded in empowering youth work practices, research is not predicated on or justified by empowering participants or enacting equality, practising social justice or democracy (e.g., Beebeejaun, et al., 2014, Kara, 2017, Liddiard et al., 2019). This step mutes the extensive critique of participatory and co-produced methods failure to realise the laudable aspirations (e.g. Cooke and Kothari, 2001). Furthermore, following the post-qualitative turn, eventful co-production unsettles abstract categories and settled research practices that are definitional of co-producing research (e.g. co-researchers participating in 'planning'), which might prevent us from accessing the many remainders of a world in process. In some senses more ambitious in others more modest, eventful co-production orientates the research to the practices and processes related to the realisation of events: co-producing new thoughts and feelings that create new possibilities in the world. Following speculative and process approaches, we understand co-producing research as thinking and feeling in a world in process. We turn to the careful and imaginative work of creating propositions and techniques of relation, developing our capacities to attune to the potentials that emerge and determine whether what we research Matters! Through Whitehead we can identify principles and practices that 
augment and intensify creativity. The appetitive drive determines a restless search for

561 difference and diversity in, for example, the backgrounds and experiences of the

562 young people we work with, and the in thoughts and feelings, experiences and

563 encounters, media and modalities, and regimes of practice we explore. We are not

564 triangulating findings nor applying tested methods but endlessly experimenting,

565 adapting and following emerging findings wherever they go.

566 It is important in this shift from the qualities of the relationship with specific young

567 people to a broader engagement with the potential in ideas, propositions and enabling

568 constraints that 'theory' or the necessity to be creative and think new ideas does not

569 become an additional set of pressures that work to marginalise, disempower and deny

570 the agency of young people in co-produced research. It was, however, these processes

571 of speculation, imagination and remaining open to and following the emergence of

572 new ideas and feelings whether they follow the grooves of co-production or not that

573 created my eventful realisation of Patience's contribution to the project. Patience's

574 expansive politics of care in supporting her fellow youth co-researcher co-produced a

575 significant dimension of the project but this was not a trajectory related to

576 empowerment, social justice or equality. Rather the eventful realisation hinged on my

577 actions that might be seen to disempower Patience. Yet something more powerful

578 emerged. The aim therefore is not to lose young people but rather to fold

579 commitments for young people with an ethics of the event, finding and tracing

580 multiple and eventful contributions, collaboratively creating new propositions and 581 possibilities to re-imagine a world in process. 
Autonomous Geographies Collective (2010). Beyond Scholar Activism: Making

586 strategic interventions inside and outside the Neoliberal University. ACME: An International E-Journal for Critical Geographies, 9(2), 245-275.

Bradbury-Jones, C. and Taylor, J. (2015). Engaging with children as co-researchers: challenges, counter-challenges and solutions. International Journal of Social Research Methodology. 18(2), 161-173.

Banks, S., Hart, A., Pahl, K., \& Ward, P. (2018) Co-producing research: A community development approach. In S. Banks, A. Hart, K. Pahl \& P. Ward (Eds.) Co-producing Research: A Community Development Approach. (pp. 1-18) Bristol: Policy Press. Banks, S., Armstrong, A., Carter, K., Graham, H., Hayward, P., Henry, A., Holland, T., Holmes, C., Lee, A., McNulty, A., Moore, N., Nayling, N., Stokoe, A., \& Strachan, A. (2013). Everyday ethics in community-based participatory research. Contemporary Social Science, 8(3), 263-277.

Batsleer, J. \& Duggan, J.R. (2018) Loneliness Connects Us: Young people exploring and experiencing loneliness and friendship, Project Report, ISBN: 'Loneliness Connects Us': 978-1-010029-36-7

Batsleer, J. \& Duggan, J.R. (2020) Young and Lonely: The social conditions of loneliness, Bristol: Policy Press.

Beebeejaun, Y., Durose, C., Rees, J., Richardson, J., \& Richardson, L. (2014). 'Beyond text': Exploring ethos and method in co-producing research with communities. Community Development Journal, 49, 37-53.

Beebeejaun, Y., Durose, C., Rees, J., Richardson, J., \& Richardson, L. (2015). Public harm or public value? Towards coproduction in research with, communities.

Environment and Planning C: Government and Policy, 33, 552-565.

Bell, D.M. \& Pahl, K. (2018). Co-production: towards a utopian approach. International Journal of Social Research Methodology, 21(1), 105-117

British Education Research Association (BERA) (2011). Ethical Guidelines for Educational Research. London: British Education Research Association.

Bevir, M. (2019). Inside co-production: Ruling, resistance, and practice. Social Policy \& Administration, 53, 197-202.

British Academy (2010). Past, Present and Future: The Public Value of the Humanities and Social Sciences. British Academy: London. 
617 Cacioppo, J.T. and Patrick, W. (2009) Loneliness: Human Nature and the Need for Social

618 Connection, New York; London: W.W. Norton and Company.

619 Cooke B. and Kothari U. (Eds). (2001). Participation: The New Tyranny? Zed Books:

620 London.

621 Co-op Foundation (2018) All Our Emotions are Important, Retrieved from:

622 https://www.coopfoundation.org.uk/youth/all-our-emotions-research/

623 de St Croix, (2016). Grassroots youth work: Policy, passion and resistance in practice.

624 Bristol: Policy Press.

625 Dentith, A., Measor, L., \& O'Malley, M.P. (2009). Stirring Dangerous Waters:

626 Dilemmas for Critical Participatory Research with Young People. Sociology, 43(1), 158-

627168.

628 Durose, C., Beebeejaun, Y., Rees, J., Richardson, L. (2011). Towards Co-Production in

629 Research with Communities. Arts and Humanities Research Council Connected

630 Communities Scoping Report, Retrieved from:

631 https://ahrc.ukri.org/documents/project-reports-and-reviews/connected-

632 communities/towards-co-production-in-research-with-communities/

633 Enright, B., Facer, K., \& Larner, W. (2016). Reframing co-production: Gender,

634 relational academic labour and the university. In E. Jupp, J. Pykett, F.M. Smith (Eds.)

635 Emotional States: Sites and Spaces of Affective Governance, (pp. 36-51). London:

636 Taylor \& Francis Group.

637 Ersoy, A. (2017). Introduction in A. Ersoy (Ed.) The Impact of Co-production: From

638 Community Engagement to Social Justice. (pp. 1-8) Bristol: Policy Press.

639 Facer, K. \& Enright, B. (2016). Creating Living Knowledge: The Connected Communities

640 Programme, community university relationships and the participatory turn in the

641 production of knowledge. Bristol: University of Bristol/AHRC Connected Communities.

642 Facer, K. \& Pahl, K. (2017). Introduction. In K. Facer and K. Pahl, Valuing

643 interdisciplinary collaborative research: Beyond impact. (pp. 1-21) Bristol: Policy

644 Press.

645 Fisher, M. (2009). Capitalist Realism. Is there no alternative? London: Zed Books.

646 Foucault, M. (2007) Qu'est-ce que la critique? [What is Critique?] in The Politics of

647 Truth ed S. Lotringer /translated by L. Hochroth \& C. Porter, Camb. MA., London:

648 Semiotext(e)/MIT Press.

649 Fox, R. (2013). Resisting participation: critiquing participatory research

650 methodologies with young people. Journal of Youth Studies, 16(8), 986-999. 
651 Gaskill, N. and Nocek, A.J. (2014) An Adventure of Thought. In N. Gaskill and A.J.

652 Nocek (Eds.) The Lure of Whitehead. (pp. 1-41) Minneapolis; London: University of

653 Minnesota Press.

654 Haraway, D.J. (1985) A Cyborg Manifesto: Science, Technology, and Socialist-

655 Feminism in the Late 20th Century, Socialist Review, 80, pp. 65-108.

656 Hickey, G. Richards, T. and Sheehy, J. (2018). Co-production from proposal to paper.

657 Nature, 562(7725), 29-31.

658 Innes, M., Davies, B. and McDermot, M. (2019). How co-production regulates. Social

659 \& Legal Studies, 28(3), 370-391.

660 James, W. (1996a). Essays in Radical Empiricism. Lincoln: University of Nebraska

661 Press.

662 Kara, H. (2017). Identity and power in co-produced activist research. Qualitative

663 Research, 17(3), 289-301.

664 Kelly, P. (2001). Youth at Risk: Processes of individualisation and responsibilisation in

665 the risk society, Discourse: Studies in the Cultural Politics of Education, 22(1), 23-33.

666 Levy, F. J. (2005). Dance movement therapy: A healing art (2nd ed.). Reston, VA:

667 National Dance Association: American Alliance for Health, Physical Education,

668 Recreation, and Dance.

669 Liddiard, K., Runswick-Cole, K., Goodley, D., Whitney, S., Vogelmann, E. \& Watts, L.

670 (2019). "I was Excited by the Idea of a Project that Focuses on those Unasked

671 Questions" Co-Producing Disability Research with Disabled Young People. Children

672 and Society, 33, 154-167.

673 Manning, E. \& Massumi, B. (2014). Thought in the act: Passages in the ecology of

674 experience. Minneapolis; London: University of Minnesota Press.

675 Massumi, B. (2011). Semblance and Event: Activist Philosophy and the Occurrent Arts.

676 Cambridge, MA.; London: The MIT Press.

677 May, T. (2012). Friendship in an Age of Economics: Resisting the Forces of

678 Neoliberalism. New York: Lexington Books.

679 Nesta (2012). People Powered Health Co-production Catalogue. London: NESTA.

680 Ostrom, E. (1996). Crossing the Great Divide Coproduction, Synergy, and

681 Development. World Development, 24, 1073-1087.

682 St. Pierre, E. (2019). Post Qualitative Inquiry in an Ontology of Immanence,

683 Qualitative Inquiry, 25(1), 3-16. 
Pemberton, S. \& Mason, J. (2009). Co-production and Sure Start Children's Centres: Reflecting upon Users', Perspectives and Implications for Service Delivery, Planning and Evaluation. Social policy and society, 8(1), 13-24.

Perry, B. \& Atherton, M. (2017). Beyond critique: the value of co-production in realising just cities? Local Environment, 22(1), 36-51.

Qualter, P., Brown, S.L., Rotenberg, K.J., Vanhalst, J., Harris, R.A., Goossens, L., Bangee, M., Munn, P. (2013) Trajectories of loneliness during childhood and adolescence: Predictors and health outcomes. Journal of Adolescence, 36, 12831293.

Rogaly, B. (2016). 'Don't show the play at the football ground, nobody will come': the micro-sociality of co-produced research in an English provincial city. The Sociological Review, 64, 657-680

Rousell, D. (2017). Mapping the Data Event: A posthumanist approach to art| education/research in a regional university. In L. Knight \& A. Cutcher, Arts, Research, Education: Connections and directions (pp. 203-220). New York: Springer International Publishing.

Shaviro, S. (2009). Without Criteria: Kant, Whitehead, Deleuze, and Aesthetics. Cambridge, MA, London: MIT Press.

Stengers, I. (2011). Penser avec Whitehead [Thinking with Whitehead: a free and wild creation of concepts]. Harvard, London: Harvard University Press.

Stengers, I. (2019). Putting Problematization to the Test of Our Present. Theory, Culture \& Society, OnlineFirst.

Thomas-Hughes, H. (2018a). Critical Conversations with Community Researchers Making Co-Production Happen? Bristol: University of Bristol and AHRC Connected Communities. Retrieved from: https://connectedcommunities.org/index.php/project_resources/connected-communities-catalystfund- reports-2016-18/

Thomas-Hughes, H. (2018b) Ethical 'mess' in co-produced research: reflections from a U.K.-based case study, International Journal of Social Research Methodology, 21(2), 231-242.

Tiffany, G.A. (2009). Community Philosophy: A project report. York: Joseph Rowntree Foundation (JRF).

Truman, S.E., \& Springgay, S. (2015). The primacy of movement in research-creation: New materialist approaches to art research and pedagogy. In M. Laverty \& T. Lewis (Eds.), Art's teachings, teaching's art: Philosophical, critical, and educational musings. Springer. pp. 151-162. 
720 United Nations. (1989). Convention on the Rights of the Child. HMSO: London.

721 Vostal, F. (2016). Accelerating Academia: The Changing Structure of Academic Time.

722 London; New York: Palgrave Macmillan.

723 Vromen, A. \& Collin, P. (2010). Everyday youth participation? Contrasting views from

724 Australian policymakers and young people. Young: Nordic Journal of Youth Research, 725 18(1), 97-112.

726 Whitehead, A.N. (1964) The Concept of Nature. Cambridge: Cambridge University 727 Press.

728 Whitehead, A.N. (1967) Science and the Modern World. New York: The Free Press.

729 Whitehead, A.N. (1978) Process and Reality: Corrected Edition, (Eds.) D.R. Griffin and 730 D.W. Sherburne. New York: The Free Press.

731 Youdell, D., \& McGimpsey, I. (2015). Assembling, disassembling and reassembling 732 'youth services' in Austerity Britain. Critical Studies in Education, 56(1), 116-130. 